\title{
Rape and Other War Crimes in Chechnya: Is There a Role for the International Criminal Court?
}

\author{
W. ANDY KNIGHT \& TANYA NAROZHNA
}

Two recent Chechen-Russian wars have taken a disastrous toll on the civilian population and produced numerous allegations of grave breaches of the Geneva Conventions and of other horrendous violations of international humanitarian law. Charges of extrajudicial executions, forced disappearances, murder, rape and torture have been leveled against both the Moscow government/federal troops, as well as against Chechen rebels. ${ }^{1}$

In 2000, Sergey Yastrzhembsky, Putin's media policy advisor, announced that Russian authorities had information on 427 cases of alleged crimes committed by federal forces in Chechnya. Yet, only 29 investigations were opened into these allegations of human rights abuse. ${ }^{2}$ Last year, President Putin declared that the military prosecutor's office had investigated 127 crimes committed against Chechen civilians by Russian troops. However, Oleg Orlov, the chairman of the Memorial human rights group that has been monitoring the situation in Chechnya for several years, has charged that many of these cases were dropped before being brought to court. "There have been thousands of complaints from victims, but by the end of January only 162 cases had come to court. Out of 97 cases investigated in 2002, 40 were dropped for lack of evidence. Overall, only 46 Russian servicemen have been convicted." 3 Nevertheless, the growing number of charges has propelled international humanitarian concern. 
On February 24, 2001, a dumping ground filled with human remains was discovered in a village called Dachny, which is located less than a kilometer away from Russia's main military base in Chechnya. Fifty-one bodies were found in this mass grave. Nineteen of those bodies were identified, and of those at least sixteen were the remains of individuals who were last seen alive in the custody of Russian federal forces. Most were dressed in civilian clothing. Some were blindfolded, and many had their hands and/or feet bound. This mass "dumping site" - the bodies were dumped along streets in the village and in abandoned cottages over an extended period of time - provides concrete evidence of the Russian federal forces' practice of forced disappearances, torture, and extrajudicial execution in Chechnya. The mass "dumping ground" has been under Russian military control since December 1999, long before the vast majority of the bodies were deposited there. However, the Russian government's investigation into this case has been woefully inadequate. Russian authorities, in the course of their investigation, failed to preserve potentially crucial evidence that could have led to the identification of those responsible for the mass killings.

Dachny is not the only such site of unmarked graves to be found in Chechnya. In March 2001, Human Rights Watch issued a report titled, "The 'Dirty War' in Chechnya: Forced Disappearances, Torture and Summary Executions," that documented eight mass graves and eight other makeshift burial sites where corpses of the "disappeared" and others had been found. ${ }^{4}$ Human Rights Watch, Amnesty International, the Medical Foundation for the Care of Victims of Torture and the Memorial Human Rights Center have all urged Moscow on numerous occasions to properly investigate, and establish a meaningful accountability process for, the thousands of cases of forced disappearances, torture and extrajudicial executions that have occurred in Chechnya. In spite of these calls, legal bodies in Russia have time and again rejected the pleas of these bodies. The 2004 Council of Europe report released last January revealed that over the past three years nearly 10,000 human rights abuse claims had been brought before the Office of Russia's special representative in Chechnya. Yet, investigations into most of those complaints were rarely ever completed. ${ }^{5}$ Given the Russian government's intransigence on this issue, it is understandable that Chechen victims of Russian human rights abuse would want to try to seek redress outside of Russia. Some victims, and families of victims, of human rights abuse in Chechnya have begun to take their cases to the European Human Rights Court. Indeed, "the Strasbourg- 
based European court has already accepted several cases. A total of 150 lawsuits have been filed by Chechens." 6

While both Russian and Chechen sides have often been accused of resorting to harsh methods during the conflict, Western criticism of Russian policy in Chechnya has been greatly subdued since the September 11, 2001 terrorist attacks on the US homeland. Immediately after the attacks, many world leaders began to accept Moscow's assertion that there was a link between Chechen rebels and international terrorism. The US administration seems to have bought the argument made by the Russian President that his government's war in Chechnya is a contribution to the US-led global counter-terrorist campaign. The general response of the international community to the accusations of Russian human rights abuse in Chechnya has been restrained by the oft repeated argument that the struggle between Chechnya and Russia is an internal conflict that the Russian government reserves the right to resolve without outside interference.

The Chechen situation has been shielded from the scrutiny of the UN Commission on Human Rights (UNCHR). While the UNCHR has condemned the human rights abuses in Chechnya, it stopped short of creating an international commission of inquiry, requiring only that Russia establish a national commission of inquiry. This body is obviously sensitive to Russia's insistence that the "Chechen problem" is a domestic and not international one. In 2002, Russia refused to extend the mandate of the Organization of Security Co-operation in Europe (OSCE) assistance group that was responsible for reporting on human rights conditions, facilitating humanitarian relief, and promoting a peaceful resolution to the crisis. ${ }^{7}$ No improvement was observed in 2003. Aside from well-intended and strongly worded declarations of concern, the international community has failed to devise any political or financial enforcement measures to remedy the humanitarian situation in Chechnya. An initiative of the Parliamentary Assembly of the Council of Europe (PACE) could have provided a potential breakthrough. ${ }^{8}$ In the spring of 2003, PACE passed a resolution that proposed the creation of a special ad hoc war crimes tribunal to safeguard the rights and freedoms of Chechens and to ensure that all crimes against humanity are investigated, regardless of the perpetrators' ethnicity. Unfortunately, realpolitik worked against the PACE initiative, and Russia's dramatic rollback of human rights and the rule of law once again topped the agenda of the EU-Russia summit in November 2004. 
This article aims to accomplish two purposes. First, it analyzes the nature and scope of violations of humanitarian law, focusing especially on sexual violence in Chechnya, to determine the extent to which a climate of impunity exists that would warrant international intervention in order to hold those responsible for these abuses accountable. Second, the article evaluates prospects for the progressive efforts by the international community, particularly through the International Criminal Court (ICC), to break the cycle of violence, rape and abuse in Chechnya, to halt atrocities perpetrated against the civilian population, and to prosecute alleged perpetrators. By discussing the work done to develop international criminality around rape and showing how this issue was inserted in the Rome Statute, this part of the article will demonstrate the reasons why the International Criminal Court may be needed to deal with crimes against humanity committed in Chechnya.

THE SCOPE OF SEXUAL VIOLENCE IN CHECHNYA

The soldiers took the girl into an empty house and sometime later they returned her, saying "Hide this bitch somewhere. More soldiers are coming after us, they will kill and rape her anyway." She was seventeen or eighteen. This is not the only case; a married woman was also raped. But people keep it a secret, they say she was not raped because it causes such great shame. People just don't speak about it. ${ }^{9}$

Disclosing and documenting the widespread use of sexual violence and rape against the civilian population during the war in Chechnya is an extremely difficult task for two reasons: 1) because of the attempts by the Russian government to suppress this information, and; 2) because of the cultural taboo and religious stigma attached to such issues within the Muslim tradition. The mother of a young girl who was raped and then killed during an interrogation session by Russian soldiers is known to have said that in Chechen society "rape is worse than murder." 10 The surviving female victims of sexual violence are generally ostracized from Muslim communities and, in the case of unmarried survivors, are extremely unlikely to wed if the incidence of rape becomes public knowledge.

Until recently, aside from sporadic disturbing testimonies of rape victims, it was difficult to find a substantial body of reliable evidence of sexual abuse in Chechnya. ${ }^{11}$ This situation has changed recently. In the spring of 2004, the British Medical Foundation for the Care of Victims of 
Torture published "Rape and Other Torture in the Chechnya Conflict"the first systematic and substantiated study to produce medical and psychological documentation of thirty-five asylum seekers (nineteen women and sixteen men) from the Chechnya conflict at the Medical Foundation's treatment centre in London. Sixteen women and one man disclosed that they had been raped. In thirteen of the cases the rape was allegedly carried out by Russian soldiers, in three cases, the alleged perpetrators were said to be Russian police officers, and in the final case, the victim claimed that the perpetrators were Chechen rebels. ${ }^{12}$ The medico-legal reports prepared by professionals who had years of experience dealing with victims of sexual violence provided evidence that rape as a method of torture is broadly and consistently being used as a tool of war in the Chechen-Russian conflict. This study confirmed that more than half of the rape victim survivors felt shame and feared dishonor or stigmatization. One female victim who conceived a child as a result of the rape was insulted, tormented, and even physically assaulted by another woman in her community once her pregnancy and rape became public knowledge. One victim exclaimed: "so great is the stigma attached to rape, many Chechen women commit suicide rather than live with the burden of their shame." Another woman witnessed the suicide of her cellmate who had been raped, which essentially confirms the above point. ${ }^{13}$ Rapes in Chechnya occur in the villages, at checkpoints, and in detention centers. Fear of rape is so pervasive that many families flee in a desperate attempt to protect their female members.

Despite the cultural and religious taboos against speaking out on this issue, testimonies of sexual assaults in Chechnya have continued to surface. At the same time, Russian law enforcement agencies have more often than not failed to launch serious investigations or to prosecute the perpetrators of such crimes. This only serves to perpetuate the existence of a climate of impunity.

One of the most serious tests for Russia's military justice system was the high profile trial of Colonel Budanov. Yuri Budanov (38), a rising star in the Russian army and a hardened veteran of both Chechen wars, was decorated with two medals for valor, including the Order of Virtue. This high-ranking officer had moved quickly up the ranks of the Russian army and was about to be promoted to General when his brilliant career was suddenly and dramatically stalled. The reason? Budanov became the first Russian officer to be publicly tried for crimes committed against civilians in Chechnya. On the night of March 27, 2000, after celebrating his daughter's birthday, Budanov decided to act on an intelligence report that 
a sniper collaborating with Chechen rebels lived in the village of TangiChu. Around midnight, Budanov in a drunken rampage, together with three other soldiers, kidnapped eighteen-year-old Kheda (Elza) Kungaeva from her father's home and brought her to a secluded military encampment. During the interrogation, Budanov allegedly beat, raped, and strangled Kheda Kungaeva, and then ordered his men to bury her.

A few days later, Budanov was arrested and charged with homicide, kidnapping and abuse of power. He admitted to strangling the girl but claimed to be in a "state of temporary insanity." However, he vociferously denied raping the girl or acting in a premeditated manner. An autopsy report obtained by the Kungaeva family revealed, however, that the victim had indeed been raped. This new evidence undermined the argument by Budanov's defense that he had acted in a fit of rage. Nevertheless, the final report somehow failed to make mention of the rape and ultimately the charge of sexual assault against Budanov was dropped. On March 29, 2000, the Chief of the Russian Army General Staff, Anatoly Kvashnin, said of the incident: "it is a savage and shameful event for the armed forces. Budanov has shown himself to be a bandit in relation to the civilian population. Scumbags like that should be rooted out of the army collective."14 Following his arrest, Budanov underwent psychiatric examination in two different hospitals and was declared to have been responsible for his actions. A year later, on April 21, 2001, the case finally went to court. Budanov was once again sent to the Serbsky State Scientific Center for Social and Forensic Psychiatry in Moscow for a psychiatric examination. This time the examination concluded that he was not mentally responsible for his actions. In late 2002, a district court ordered him to undertake a compulsory in-patient psychiatric treatment. But two months later, on February 28, 2003, the Russian Supreme Court's Military Collegium reversed the earlier decision of the district court and ordered a retrial. On July 25, 2003, Budanov was found guilty, sentenced to ten years in prison, and stripped of his military rank and order. On May 17, 2004, he filed an appeal for a pardon. In the fall of that year a commission in Ulyanovsk recommended that Budanov be pardoned. This initiative was supported by the regional governor, Vladimir Shamanov, Budanov's former commanding officer in Chechnya. Under pressure from human rights groups and the government of Chechnya, and in light of growing protests in Chechnya, Budanov retracted his request for pardon.

The Budanov case has become a political issue with serious repercussions for Russian policy and rhetoric with respect to the antiterrorist cause. For over two years, Russia's military justice system has 
been paralyzed, unable to decide on Budanov's sanity even after ordering six medical examinations. Russian authorities have turned "to a familiar partner from Soviet times, a psychiatric profession that for decades followed orders to camouflage political problems behind the opaque curtain of mental illness. In doing so, however, officials have resurrected questions about psychiatry's shameful past in the Soviet Union - and its highly politicized present." 15 Moscow authorities used this case to attain their political goals. They demonized Budanov before the elections in Chechnya and gained important votes. However, after the election was held, they were silent about their earlier declared readiness to punish him. Meanwhile, Budanov is now celebrated as a national hero in Russia. Polls conducted by Komsomolskaya Pravda, a Moscow-based daily, showed that some $79 \%$ of Russia's population supports him. ${ }^{16}$ Budanov's trial has demonstrated the Russian national authorities' lack of political will and the ambivalent attitudes of ordinary Russians about bringing to justice those responsible for abuse during the wars in Chechnya. Domestic politics has become a clear obstacle to enforcing human rights in Chechnya, creating a need for outside intervention to ensure that these incidences of human rights abuse in Chechnya do not go unpunished.

\section{IS THERE A ROLE FOR THE INTERNATIONAL}

\section{CRIMINAL COURT?}

On September 13, 2000, the Russian Federation signed the multilateral treaty, the Rome Statute, which took force on July 1, 2002. Russia has yet to ratify this statute. ${ }^{17}$ Perhaps one reason for not doing so is their anticipation that Russian military and political leaders could eventually wind up before this international criminal court facing charges of crimes against humanity during the Chechnya campaign. After all, the US government, also concerned about the possibility that its military and political leaders could be indicted for war crimes and crimes against humanity, not only refused to ratify the Rome Statute but also withdrew its signature from the document. On May 7, 2002, when US President George W. Bush announced the US's withdrawal, US Secretary of Defense Donald Rumsfeld was quoted as saying, "The United States will regard as illegitimate any attempt by the court or state parties to the treaty to assert the ICC's jurisdiction over American citizens."18 Therefore, one can understand the reluctance of Russian government officials to fully endorse the Rome Statute. 
Whether or not there is a role for the International Criminal Court (ICC) in addressing the issue of rape and other war crimes being committed in Chechnya is really a matter of academic debate until Russia decides to ratify this multilateral treaty. But it bears mentioning that the ICC was created precisely to deal with war crimes (like rape) and other crimes against humanity that are not being addressed adequately by national courts. It is fair to say, from the evidence provided above, that the Russian national courts have not properly responded to accusations of Russian military abuses in Chechnya.

It is also important to bear in mind that it took almost seventy years of debate and deliberation over the need for a permanent criminal court at the international level before action was finally taken to bring one into being. Of particular interest here is the foundational legal work done to ensure that war crimes such as rape be included in the new international humanitarian law that would govern the operations of the ICC.

In the past, rape and acts of sexual violence committed against women during conflict situations generally went unrecognized and unchallenged. In many of these conflicts, both military and political leaders tended to view rape more often than not as a fringe benefit or perk of war. More recently, however, particularly after the revelations of organized, systematic patterns of mass rape in the Yugoslavian conflict, there has been an effort to treat rape as a war crime. While there is no evidence that Russians soldiers are using rape in a systematic way or as a deliberate strategy of ethnic cleansing, as has been charged in other cases, there is still a sense that rape and other war crimes have been used in the Chechnya campaign to demoralize the "enemy."

Today, instances of rape during conflicts are less tolerated than previously. However, the crime of rape has long existed under customary international law. One can go back to 1474 when Peter von Hagenbach was convicted of a number of offenses, including rape, and ordered to be executed. ${ }^{19}$ The Leiber Code, signed by President Abraham Lincoln in 1853, listed rape as a specific offense and made it a capital offense punishable by death (see article 44). The Code was adopted as international law in 1907 at an international peace conference in Copenhagen. The Hague Conventions, the World War II prosecutions, and the Geneva Conventions all reinforced prohibitions against rape and other sexual violence during times of war. Although it was not codified in their Charter, some evidence of sexual violence was presented after World War II to the International Military Tribunals, most notably, the International Military Tribunal for the Far East where rape was first 
specifically referenced in the judgments. In the Tokyo Trials, although rape and other acts of sexual violence fell within the general category of "Crimes Against Humanity" and were not treated as separate substantive war crimes, the prosecuting lawyers did make an attempt to put forward evidence of the sexual atrocities committed against women in Nanking, Borneo, the Philippines, and French Indo-China. The Allied Control Council Law No. 10, under the heading of "Punishment of Persons Guilty of War Crimes, Crimes against Peace and Against Humanity," specifically listed rape as a war crime in its charter.

This legal foundation has allowed those responsible for the development of our new body of international humanitarian law to make rape and other violent sexual acts part of the list of prohibited war-time activity and has put the international community in a better position to investigate, document, and prosecute rape and other forms of sexual violence. Rape and sexual violence are now clearly enumerated offenses under international humanitarian law, particularly after 1993 and 1994 when such violations were specifically codified for the first time as recognizable and independent crimes within the statutes of the International Criminal Tribunals for the Former Yugoslavia (ICTY) and for Rwanda (ICTR). These two documents are part of the legal foundation upon which the ICC was built. The two ad hoc tribunals have, in effect, provided solid case law for prohibiting rape and sexual violence during wartime.

Those ICTY and ICTR cases have reinforced the legal basis for arguing that rape and sexual violence are separate "crimes against humanity" and that they constitute specific violations of the laws and customs of war. This jurisprudence coming from the tribunals has set the precedent for the criminal prosecution of anyone involved in such war crimes. It essentially began with the prosecution of Jean-Paul Akayesu, who was accused of using rape and acts of sexual violence for the purpose of intimidation, degradation, humiliation, discrimination, punishment, control and the destruction of a person. What came out of the Akayesu case was that rape, like torture, must be considered a violation of personal dignity and as constituting torture particularly when it is done with the consent of a public official or someone acting in an official capacity. What we also learn from the Akayesu decision is that rape or sexual violence can be prosecuted as genocide if there is evidence to show that it was done to physically or psychologically destroy individuals or members of a group.

The ICTY has also provided similar legal precedents in the cases of Celebici, Furudzija, and Delalic. In the judgments handed down against 
these individuals, rape was recognized as a violation of the Laws and Customs of War and as a basis of torture under the Geneva Conventions. In the cases of Celebici, Furudzija and Delalic, the ICTY pointed to the despicable nature of the act of rape during wartime and to the fact that this act struck at the very core of human dignity and physical integrity.

The development of humanitarian law to address instances of rape and sexual violence has continued under the ICC Statute. Even the United States was a strong advocate for the inclusion of rape and sexual violence as specific offences for the world body to punish, during the preparatory meetings leading up to the signing of the Rome Statute.

The ICC was intended to complement national criminal justice systems, not to replace them. With the kind of evidence that has been produced recently of rape and sexual violence in the Chechnya campaign, the onus is up to the Russian government to prosecute vigorously the perpetrators of these war crimes and crimes against humanity. If the national courts of the Russian government fail to prosecute these crimes, then the argument for the utilization of the International Criminal Court is strengthened. However, the court cannot address those cases until Russia ratifies the Rome Statute and acknowledges that the victims of those crimes cannot get a fair hearing in the country's national courts.

As Holly Cartner, executive director of the Europe and Central Asia division of Human Rights Watch has put it: "It would certainly be a step in the right direction if the Russian government actually prosecuted a serviceman for rape... But a single prosecution wouldn't begin to address the problem. There have been hundreds of war crimes, including summary executions and rapes, committed by Russian soldiers in Chechnya." 20

\section{E N D N O T ES}

1 Although Russia has tried to keep military and civilian casualty figures of the Chechnya-Russian wars secret, according to the most reliable estimates, during the first and second wars in Chechnya, out of a Chechen population of 1 million, 150,000-200,000 civilians have died or disappeared. This amounts to approximately $15 \%-20 \%$ of the entire Chechen population. Roughly 30,000-40,000 children have died and 20,000-40,000 Russian soldiers have lost their lives over the same period. Casualty figures of Chechen forces over that time are comparable. See http://www.hrvc.net/main.htm. 
"UN Commission's resolution on Chechnya: Another missed opportunity to guarantee accountability and justice," Amnesty International, April 25, 2000.

3 Asiyat Vazaeva, "Council of Europe Demands Chechnya Tribunal," Institute for War and Peace Reporting, April 14, 2003.

4 Human Rights Watch, "The 'Dirty War' in Chechnya: Forced Disappearances, Torture, and Summary Executions," A Human Rights Watch Report, vol.13, no.1 (D), March 2001.

5 "Russia Scraps Kremlin's Human Rights Post in Chechnya," January 22, 2004; available at

http://www.reliefweb.int/w/rwb.nsf/480fa8736b88bbc3c12564f600 4c8ad5/2c288a06ef2e2e89c1256e230051f6fd?OpenDocument.

6 Asiyat Vazaeva, "Council of Europe Demands Chechnya Tribunal," Institute for War and Peace Reporting, April 14, 2003.

7 The OSCE Assistance Group to Chechnya was established by the Permanent Council on April 11, 1995 (PC.DEC/35), with a mandate to promote respect for human rights, facilitate the delivery of international humanitarian aid, provide assistance for the speedy return of refugees and displaced persons, and promote a peaceful resolution of the crisis in the Republic. See http://www.osce.org/docs/english/misc/anrep01e_activ.htm\#000 12, accessed on December 12, 2004.

8 See http://assembly.coe.int/EMB_NewsView.asp? ID=471, accessed on December 12, 2004.

9 Malcolm Hawkes, "Russia/Chechnya: February 5: A Day of Slaughter in Novye Aldi," Human Rights Watch (2000).

10 "Breaking the Silence on Rape in Chechnya," The Wire, Amnesty International's monthly magazine, http://web.amnesty.org/web/wire.nsf/March2004/Chechnya, accessed on December 12, 2004.

11 See, for example, "Russian Federation: Continuing Torture and Rape in Chechnya," Amnesty International, News Service Nr. 110 - June 8, 2000,

www.reliefweb.int/w/rwb.nsf/0/d8ad11c9965aa303c12568f9004d6 748?OpenDocument, accessed on 12 December 2004.

12 Dr Charlotte Granville-Chapman, "Rape and Other Torture in the Chechnya Conflict: Documented Evidence from Asylum Seekers Arriving in the United Kingdom," April 2004, 
http://www.torturecare.org.uk/publications/reportChech.htm, accessed on December 12, 2004.

13 Ibid.

14 History of the Budanov Case, Kommersant, September 18, 2004, http://www.kommersant.com/tree.asp?rubric $=0 \&$ node $=1 \&$ doc_id $=506503$

15 Susan B. Glasser, "Psychiatry's Painful Past Resurfaces in Russian Case Handling of Chechen Murder Reminds Many of Soviet Political Abuse of Mental Health System," The Washington Post, December 15, 2002; p. A37.

16 Yuri Zarakhovich, "Who's On Trial? What the trial of a Russian colonel for the murder of a Chechen girl says about the state of Russia," Time, April 3, 2001,

http:/ / www.time.com/time/europe/eu/magazine/0,13716,104886 ,00.html, accessed on 12 December 2004.

17 The Statute was adopted on July 17, 1998, by the United Nations Diplomatic Conference of Plenipotentiaries on the Establishment of an International Criminal Court (ICC).

18 Jim Garamone, "US withdraws from International Criminal Court Treaty," American Forces Press Service, released May 6, 2002. See http://www.usasurvival.org/no-icc.shtml, accessed on 20 December 2004.

19 See David J. Scheffer, US Ambassador-at-Large for War Crimes Issues Remarks, Fordham University New York, October 29, 1999, at http://www.converge.org.nz/pma/arape.htm, accessed on December 12, 2004.

20 http://www.ishipress.com/russrape.htm, accessed on December 20, 2004. 